\title{
Expression and clinical significance of basic transcription factor 3 in nasopharyngeal carcinoma
}

\author{
PING CHEN*, QI ZHONG* , ZUFEI LI, YANG ZHANG and ZHIGANG HUANG \\ Department of Otolaryngology Head and Neck Surgery, Beijing Tongren Hospital, \\ Capital Medical University, Beijing 100730, P.R. China
}

Received February 8, 2017; Accepted August 15, 2018

DOI: $10.3892 / \mathrm{ol} .2018 .9699$

\begin{abstract}
Basic transcription factor 3 (BTF3), a transcription factor and modulator of apoptosis, is differentially expressed in carcinoma. To acquire further understanding of the involvement of BTF3 in carcinoma, the present study analyzed the expression of BTF3, as well as its role in cell function in nasopharyngeal carcinoma (NPC). BTF3 transcription rates in human NPC samples ( $\mathrm{n}=46)$ and adjacent normal tissue samples $(n=46)$ were analyzed using reverse transcription-quantitative polymerase chain reaction and immunohistochemistry. BTF3-silencing in NPC cells was performed via specific small interfering RNA molecules. The function of BTF3 was analyzed by proliferation assays and colony forming assays using a Cellomic assay system. The positive expression rates of BTF3 were significantly increased in cancerous tissues compared with those in adjacent tissues $(\mathrm{P}<0.05)$. In addition, BTF3-silencing decreased cell proliferation and colony formation $(\mathrm{P}<0.01)$ in TCA-8113 and 5-8F cells. BTF3 is overexpressed in NPC, and its silencing is associated with decreased cell proliferation and colony formation, enhanced apoptosis and cell cycle regulation of TCA-8113 and 5-8F cells.
\end{abstract}

\section{Introduction}

Basic transcription factor 3 (BTF3), the $\beta$ subunit of the nascent polypeptide-associated complex (NAC), is a protein with a relative molecular mass of $27 \mathrm{kDa}(1,2)$. BTF3 was originally identified to be the initiator of transcription by

Correspondence to: Professor Zhigang Huang or Professor Yang Zhang, Department of Otolaryngology Head and Neck Surgery, Beijing Tongren Hospital, Capital Medical University, 1 Dongjiaomin Alley, Beijing 100730, P.R. China

E-mail: huangzhigang1963@sohu.com

E-mail: zhangyangent@163.com

*Contributed equally

Key words: basic transcription factor 3, head and neck squamous cell carcinomas, small interfering RNA, cell function
RNA polymerase from proximal promoter elements (2-4). Subsequently, it was demonstrated to be involved in cell cycle regulation and apoptosis $(5,6)$. Several previous studies have suggested that BTF3 may decrease programmed death (7-9). In addition, it was also reported to be connected with growth development and morphogenesis (8).

An increasing volume of research has focused on the presence of BTF3 in malignant tumors, and BTF3 has been demonstrated to be overexpressed $(9,10)$. By contrast, silencing of BTF3 results in decreased expression in the genes associated with tumor cell viability, including Eph receptors B2 (11).

In cancer, a significant volume of research has focused on the carcinomatous effects of BTF3, while there has been less research on squamous cell carcinoma and cell function $(9,10)$. In particular, to the best of our knowledge, there has been no research examining nasopharyngeal carcinoma (NPC). Preliminary studies regarding biological treatments targeting epidermal growth factor receptor (EGFR) and angiogenesis have been performed (12). However, clinical implications of other novel targeted therapies remain in the initial stages (12). The prognosis for advanced NPC is very poor (12); however, early-stage NPC is potentially curable. Therefore, early identification by screening may lead to an improved patient outcome (13).

In the present study, the expression of BTF3 mRNA and protein in NPC and normal samples was analyzed. siRNA-BTF3 was then used to downregulate BTF3 expression in TCA-8113 and $5-8 \mathrm{~F}$ cells, and the changes in cell proliferation and colony formation were measured to investigate the association between BTF3 and NPC.

\section{Materials and methods}

Clinical data. Patients with NPC admitted between September 2009 and January 2013 and treated at Beijing Tongren Hospital (Beijing, China) were included in the present study. A total of 42 male and 4 female patients with a median age of 62 years (range, 35-72), who had not received any other treatments prior to surgical resection, participated in the present study. All samples were confirmed histologically and all biopsies were obtained with the written consent of the patients. Immediately following surgical excision, a tumor sample was obtained from the tumor area, while corresponding peripheral normal nasopharyngeal tissue was obtained from 
associated non-cancerous tissue within $1 \mathrm{~cm}$ of the tumor without affecting the assessment of the tumor margins. The biopsies were divided into two parts: One snap-frozen in liquid nitrogen immediately following surgical resection, and stored at $-80^{\circ} \mathrm{C}$ for reverse transcription-quantitative polymerase chain reaction (RT-qPCR) and the other fixed in $4 \%$ paraformaldehyde solution at $4^{\circ} \mathrm{C}$ for $12-24 \mathrm{~h}$ and then paraffin embedded for histological analysis. The present study was approved by the Ethics Committee of Beijing Tongren Hospital Capital Medical University (approval no. TRECKY2014-027; Beijing, China).

Cell culture. The TCA-8113 and 5-8F cell lines purchased from Shanghai GeneChem Co., Ltd., (Shanghai, China), were cultured in complete Dulbecco's modified Eagle's medium (DMEM; Beijing Neuronbc Laboratories Co., Ltd., Beijing, China), supplemented with $10 \%$ fetal calf serum (FBS; Gibco; Thermo Fisher Scientific, Inc., Waltham, MA, USA), and incubated at $37^{\circ} \mathrm{C}$ in a $5 \% \mathrm{CO}_{2}$ atmosphere.

Immunohistochemistry. The BTF3 antibody was purchased from Abcam (ab66940). Tumor tissue and corresponding adjacent normal nasopharyngeal tissue were preserved by paraffin embedding. A positive biopsy was used for 3,3'-diaminobenzidine (DAB) staining of the positive control, and the antibody was replaced with phosphate-buffered saline for staining of the negative control. The working concentration of rabbit anti-human BTF3 monoclonal antibody was $1: 100$, at $4^{\circ} \mathrm{C}$ overnight. DAB staining was contrasted with $0.5 \%$ hematoxylin at $37^{\circ} \mathrm{C}$ for $2 \mathrm{~min}$. Yellow to brownish-yellow granules in cells were considered to indicate positive cells. Positive cells were counted in five randomly selected fields of view under a light high-power microscope (magnification, $\mathrm{x} 400$ ) and scored according to the positive expression rate $(0$ points for $<10 \%$; 1 point for $11-20 \%$; 3 points for $21-50 \%$; and 4 points for $>50 \%$ ) and staining intensity ( 0 points for no staining; 2 points for weak staining; and 3 points for strong staining). The sum of the points for staining intensity and positive expression rate was used as the expression score. A score $\geq 3$ was considered to indicate a positive case while a score of 0-2 was classified as a negative case.

Reverse transcription-quantitative polymerase chain reaction (RT-qPCR). The RNA of clinical specimens was extracted using the Rneasy ${ }^{\circledR}$ Micro kit (cat no. 74004; Qiagen $\mathrm{GmbH}$, Hilden, Germany) and DNA was digested from RNA specimens using the ReverTra Ace qPCR RT Master mix with gDNA Remover (FSQ-301; Toyobo Life Science, Osaka, Japan). Primer amplification was performed using a SYBR Premix Ex Taq kit (Toyobo Life Science, QPS-201). The real-time PCR included $0.5 \mu \mathrm{l}$ upstream and downstream primers, and $1 \mu \mathrm{l}$ template with an iCycler real time PCR instrument (Bio-Rad Laboratories, Inc., Hercules, CA, USA). The reaction conditions included $95^{\circ} \mathrm{C}$ denaturation for $15 \mathrm{sec}, 60^{\circ} \mathrm{C}$ for $15 \mathrm{sec}$ and $72^{\circ} \mathrm{C}$ for $45 \mathrm{sec}$, and were repeated for 40 cycles. The upstream and downstream primers were: $\beta$-actin forward, 5'-GCTGCC CTGAGGCACTCTTC-3' and reverse, 5'-ATCCTGTCGGCA ATGCCAGG-3'; and BTF3 forward, 5'-GCATCTCTGGCA GCGAACACT-3' and reverse, 5'-GCAAGTGGTGCTTTT CCATCC-3'.
The RNA of cell specimens with BTF3 expression was extracted using TRIzol (Invitrogen; Thermo Fisher Scientific, Inc., Waltham, MA, USA). RNA was reverse transcribed using M-MLV-RTase (Promega Corporation, Madison, WI, USA). The reaction system included $0.5 \mu \mathrm{l}$ upstream and downstream primers, and $1 \mu \mathrm{l}$ template. Primer amplification was performed using the LightCyclerFastStart DNA SYBR-Green kit (Takara Bio, Inc., Otsu, Japan; DRR041B) with the TP800 real time PCR instrument (Takara Bio, Inc.). The RT-PCR conditions included $95^{\circ} \mathrm{C}$ denaturation for $15 \mathrm{sec}, 95^{\circ} \mathrm{C}$ for $5 \mathrm{sec}$ and $60^{\circ} \mathrm{C}$ for $30 \mathrm{sec}$, and was repeated for 45 cycles. The upstream and downstream primers were as follows: GAPDH forward, 5'-TGACTTCAACAGCGACACCCA-3' and reverse, 5'-CACCCTGTTGCTGTAGCCAAA-3'; and BTF3 forward, 5'-TCCACAGTCTACACAGTCCAG-3' and reverse, 5'-CCA AGGTCACATAATGCCAGAG-3'.

Following normalization with GAPDH gene, relative quantification of BTF3 expression was performed by the $2^{-\Delta \Delta \mathrm{Cq}}$ method (14). The relative expression level of BTF3 gene was calculated compared with the reference gene (GAPDH). The relative expression level of $\mathrm{BTF} 3$ gene was equal to $2^{-\Delta \mathrm{Cq}}$, where $\Delta \mathrm{Cq}=\mathrm{Cq}$ of the target gene- $\mathrm{Cq}$ of the reference gene. The ratio of the target gene expression level between tumor tissue and control tissue was equal to $2^{-\Delta \Delta \mathrm{Cq}}$, where $\Delta \Delta \mathrm{Cq}=\Delta \mathrm{Cq}$ of tumor tissue- $\Delta \mathrm{Cq}$ of control tissue. A value $>1$ represents elevated expression, while $<1$ represents decreased expression.

siRNA viral vector construction. The BTF3 siRNA transcript template (sense, 5'-GCCGAAGAAGCCTGGGAATCA-3') was used to generate the viral vector, digested with AgeI/EcoRI enzymes (cat. no. R3552L/R3101L; New England BioLabs, Inc., Ipswich, MA, USA), and then ligated with pGCSIL-GFP vector (New England Biolabs). Following confirmation by agarose gel electrophoresis, the cloned products were assessed with PCR. The positive clones were considered to be successful siRNA viral vector constructions. PCR primer (+), 5'-CCTATTTCC CATGATTCCTTCATA-3' and primer (-), 5'-GTAATACGG TTATCCACGCG-3'. PCR was performed according to the manufacturer's protocol using an Applied Biosystems 2720 thermal cycler real time PCR instrument (Applied Biosystems; Thermo Fisher Scientific, Inc.). The thermocycling conditions included $94^{\circ} \mathrm{C}$ denaturation for $30 \mathrm{sec}, 94^{\circ} \mathrm{C}$ for $30 \mathrm{sec}, 55^{\circ} \mathrm{C}$ for $30 \mathrm{sec}, 72^{\circ} \mathrm{C}$ for $30 \mathrm{sec}$ and $72^{\circ} \mathrm{C}$ for $6 \mathrm{~min}$, and repeated for 30 cycles.

Cell interference efficiency. TCA-8113 and 5-8F cells were plated into 6 -well cell culture plate $\left(4 \times 10^{5}\right.$ cells) with DMEM containing $10 \% \mathrm{FBS}$, with a density of $\sim 30 \%$. An appropriate amount of lentivirus vector was added to the cells according to the group, the multiplicity of infection of the two cells were 10 in the TCA-8113 group and 20 in the 5-8F group. The control group comprised normal cells with viral infected negative control, whereas the experimental group was normal cells with viral infected RNAi target point. Total RNA was extracted using TRIzol (Invitrogen; Thermo Fisher Scientific, Inc., Waltham, MA, USA) and M-MLV-RTase (Promega Corporation) was used to treat cells with green fluorescent protein (GFP) expression. To evaluate the interference effect of the target point, total cells were analyzed for gene mRNA expression by RT-qPCR prior to collection at 5 days following 
Table I. The positive staining rates of basic transcription factor 3 in 46 cancerous tissues and adjacent tissues.

\begin{tabular}{lcc}
\hline Factor & Cancerous tissues & Adjacent tissues \\
\hline Positive staining number & 30 & 11 \\
High mRNA expression number & 34 & 21 \\
Total number & 46 & 46 \\
Positive staining rates (\%) & 65 & 24 \\
Reverse transcription-quantitative polymerase chain & $0.727 \pm 0.292$ & $2.353 \pm 0.445$ \\
reaction expression value (mean \pm standard deviation) & & \\
\hline
\end{tabular}
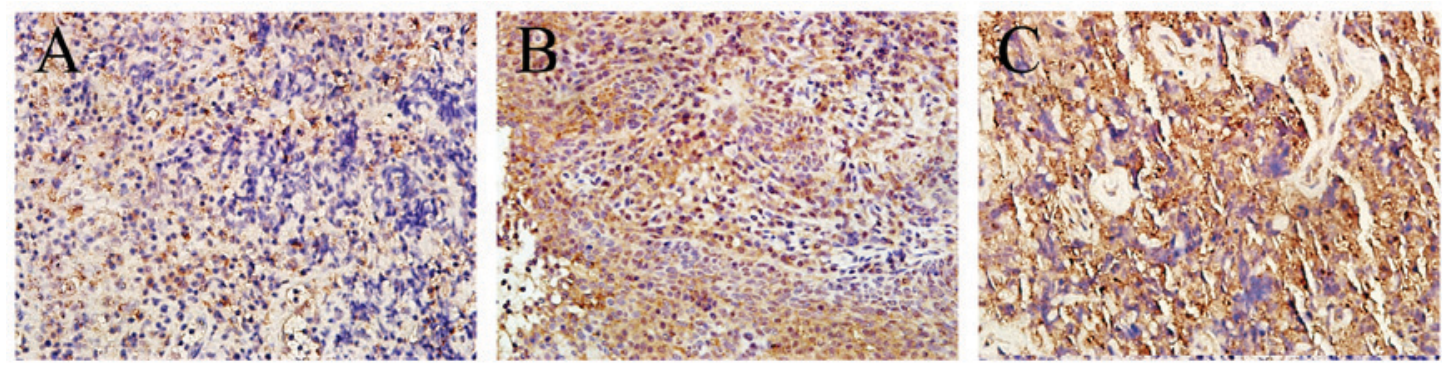

Figure 1. BTF3 immunohistochemical analysis in nasopharyngeal tissue. (A) Nasopharyngeal peri-cancerous tissue showing weak BTF3 staining in the cytoplasm. (B) NPC tissue displaying moderate BTF3 staining in the cytoplasm and nuclei. (C) Intense staining of BTF3 in NPC tumor. All images were recorded at magnification, x200 and x400. BTF3, basic transcription factor 3; NPC, nasopharyngeal carcinoma.

treatment. PCR was performed using the aforementioned primer.

Cell proliferation assay. The MTT (Sigma-Aldrich; Merck KGaA, Darmstadt, Germany) assay was used. The purple formazan crystals were dissolved using DMSO, in order to assess proliferation. Cells were seeded in 96-well plates at a density of $5 \times 10^{3}$ cells/well overnight, and then treated with the indicated doses of fluorouracil (5-FU) or gemcitabine for $48 \mathrm{~h}$. MTT ( $5 \mathrm{mg} / \mathrm{ml}$ in PBS, pH 7.4) was added to a final concentration of $0.5 \mathrm{mg} / \mathrm{ml}$. The products were solubilized with acidic isopropanol and the optical density was measured at $490 \mathrm{~nm}$ after $4 \mathrm{~h}$ of incubation at $37^{\circ} \mathrm{C}$. The growth curve was constructed and absorbance was corrected with blank readings. The experiments were performed in triplicate and repeated three times.

Colony forming assay. A total of 600 cells from the control and experimental group were plated per well into 12-well plates in triplicate. Following a 10-day culture, the colonies that had formed were analyzed under a fluorescence microscope (XDS-100; magnification, x200). Images of the whole colonies were captured with a digital camera, and then the images were used for cell numbers counting. The data were then statistically analyzed.

Follow-up. Patients were followed up by clinical appointment and telephone for survival status, disease progression, time of death (if applicable) and postoperative complications. The study cut-off was June 2015 and overall survival (OS) was defined as the time between the first surgeon's appointment and mortality from any cause. Participants who were alive at the end of the study period or lost to follow-up were censored.
Statistical analysis. Survival analysis was performed using Kaplan-Meier analysis and the multivariate Cox proportional hazard model, and significance was analyzed using the log-rank test. Data were analyzed using SPSS 17.0 statistical software (SPSS, Inc., Chicago, IL, USA). Measurement data were compared using a paired t-test. Survival status and multivariate analyses were performed using the Pearson's $\chi^{2}$ test and Cox regression analysis. The data were presented as the mean \pm standard deviation. The experiments were performed in triplicate and repeated three times. $\mathrm{P}<0.05$ was considered to indicate a statistically significant difference.

\section{Results}

Expression levels of BTF3 are increased in NPC tissues. In order to identify BTF3 in nasopharyngeal tissue, immunohistochemistry was performed. The antibody utilized recognized the BTF3a and BTF3b isoforms. In normal tissue, weak BTF3 staining was detected in the cytoplasm of cells and nuclei were not stained. In tumorous tissue, BTF3 was strongly stained in the cytoplasm and nuclei (Fig. 1). The positive staining rates of BTF3 were significantly increased in cancerous tissues $(65 \%$; $30 / 46)$, compared with those in adjacent tissues $(24 \% ; 11 / 46$; $\mathrm{P}<0.01)$ (Table I). These results indicated that the expression levels of BTF3 in NPC were increased. With the increase in the degree of tumor stage, immunohistochemical staining also increased.

$R T-q P C R$. To analyze the potential variations in mRNA expression levels of BTF3, RT-qPCR was used in NPC tissues and adjacent normal tissues. The mean expression value in tumorous tissues was $2.353 \pm 0.445$ and the value in adjacent normal tissues was $0.727 \pm 0.292$, which suggested significant 
Table II. Association between protein and mRNA expression of BTF3 and clinicopathological characteristics in 46 nasopharyngeal carcinoma cases.

\section{BTF3}

\begin{tabular}{|c|c|c|c|c|c|}
\hline Factor & Cases & Protein $(+)$ No, $\%$ & $\chi^{2}$ test $P$-value & High mRNA No, $\%$ & $\chi^{2}$ test P-value \\
\hline
\end{tabular}

\begin{tabular}{|c|c|c|c|c|c|}
\hline Age, years & & & & & 0.75 \\
\hline$\geq 60$ & 20 & 12 & 0.18 & 15 & \\
\hline$<60$ & 26 & 18 & & 19 & \\
\hline Sex & & & & & 0.24 \\
\hline Male & 41 & 27 & 0.38 & 30 & \\
\hline Female & 5 & 3 & & 4 & \\
\hline Tumor stage $^{\mathrm{a}}$ & & & & & $<0.01$ \\
\hline I-II & 14 & 5 & 0.01 & 6 & \\
\hline III-IV & 32 & 25 & & 28 & \\
\hline LNM & & & & & 0.01 \\
\hline None & 18 & 10 & 0.03 & 9 & \\
\hline Yes & 28 & 20 & & 25 & \\
\hline Distant metastasis & & & & & 0.01 \\
\hline None & 37 & 23 & 0.02 & 26 & \\
\hline Yes & 9 & 7 & & 8 & \\
\hline Smoking & & & & & 0.20 \\
\hline Frequently & 30 & 19 & 0.37 & 23 & \\
\hline None & 16 & 11 & & 11 & \\
\hline
\end{tabular}

${ }^{a}$ American Joint Committee on Cancer Cancer Staging Manual 8th edition (37). LNM, lymph node metastasis; BTF3, basic transcription factor 3.

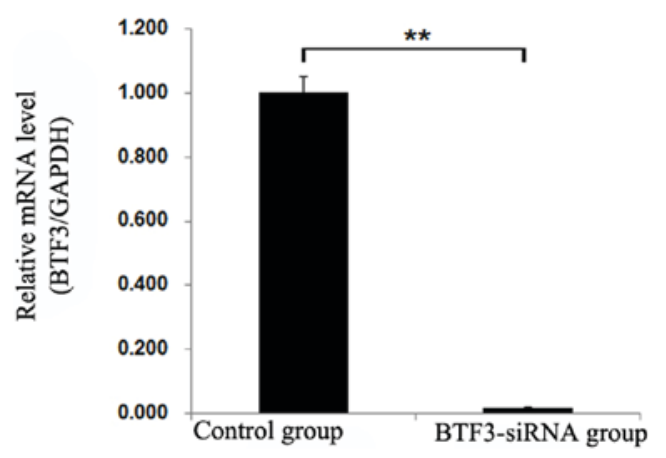

Figure 2. The mRNA levels of BTF3 in 5-8F cells. Following siRNA lentiviral infection, the BTF3 mRNA expression level was significantly inhibited in $5-8 \mathrm{~F}$ cells. ${ }^{* *} \mathrm{P}<0.01$. siRNA, small interfering RNA; BTF3, basic transcription factor 3 .

differences in gene expression levels between the cancerous and adjacent tissues $(\mathrm{P}<0.01)$ (Table I). In addition, these results indicated that the expression of BTF3 in tumorous tissue was significantly increased $(\mathrm{P}<0.05)$.

Cell interference. RT-qPCR was performed to detect potential changes in mRNA levels of BTF3 expression in experimental and control groups. The results illustrated significant differences in gene expression levels $(\mathrm{P}<0.01)$, demonstrating that siRNA-BTF3 successfully transfected into TCA-8113 and 5-8F cell lines led to decreased mRNA expression (Figs. 2 and 3).

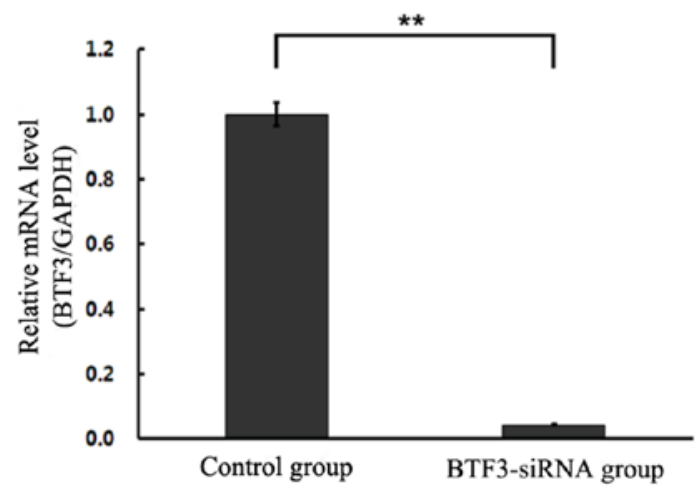

Figure 3. Quantitative PCR. Following siRNA lentivirus infection, the BTF3 mRNA expression level was significantly inhibited in TCA-8113 cells. ${ }^{* *} \mathrm{P}<0.01$. siRNA, small interfering RNA; BTF3, basic transcription factor 3 .

Cell proliferation assay. Results are presented as growth curves from day 1 to day 5 , and suggest that MTT value ratios (multiplication rate) were significantly reduced in $5-8 \mathrm{~F}$ and TCA-8113 experimental groups (Figs. 4 and 5). The results indicated that there was a significant inhibition of $5-8 \mathrm{~F}$ and TCA-8113 proliferation following siRNA lentiviral transfection $(\mathrm{P}<0.05)$.

Cell colony formation assay. In 5-8F cells, a mean of 36 colonies was detected in the siRNA BTF3 group, whereas a significantly higher mean of 110 colonies was detected in the control group ( $\mathrm{P}<0.01$; Fig. 6). Similarly, in TCA-8113 cells, a mean of 


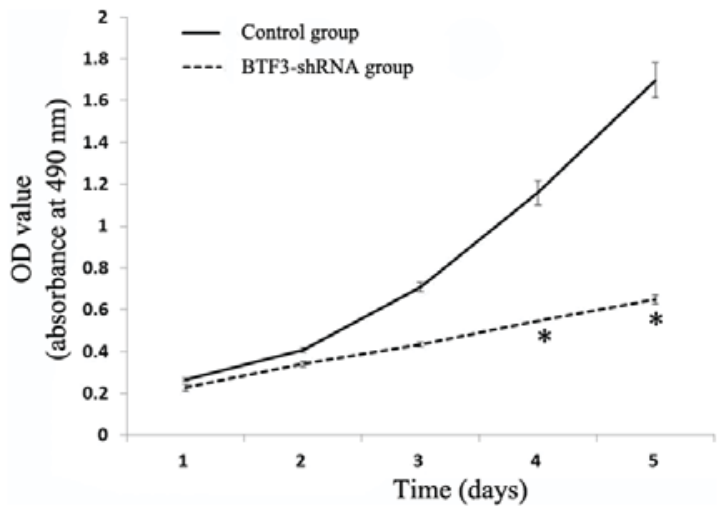

Figure 4. Growth curve of absorbance in the control group and siRNA-BTF3 group from day 1 to day 5 in $5-8 \mathrm{~F}$ cells. ${ }^{*} \mathrm{P}<0.05$, compared with the control group (days 4 and 5). OD, optical density; BTF3, basic transcription factor 3 .

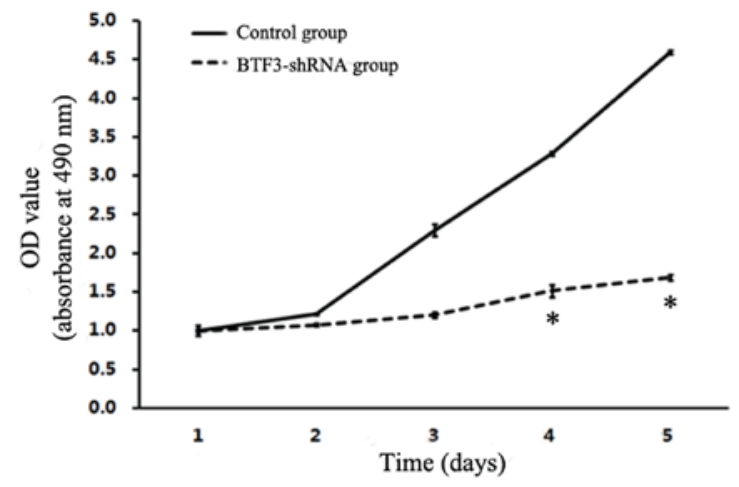

Figure 5. Growth curve of absorbance in the control and siRNA-BTF3 group from day 1 to day 5 in TCA- 8113 cells. " $\mathrm{P}<0.05$, compared with the control group (days 4 and 5). OD, optical density; BTF3, basic transcription factor 3; siRNA, small interfering RNA.

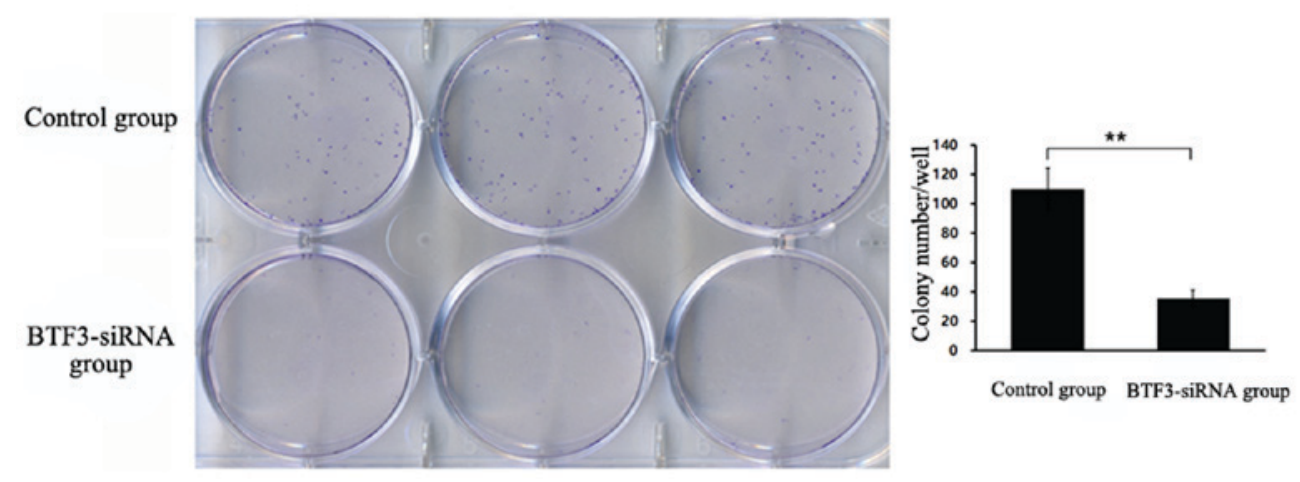

Figure 6. Mean number of colonies in control and siRNA-BTF3 groups in 5-8F cells. ${ }^{* *} \mathrm{P}<0.01$ compared with control. BTF3, basic transcription factor 3; siRNA, small interfering RNA.

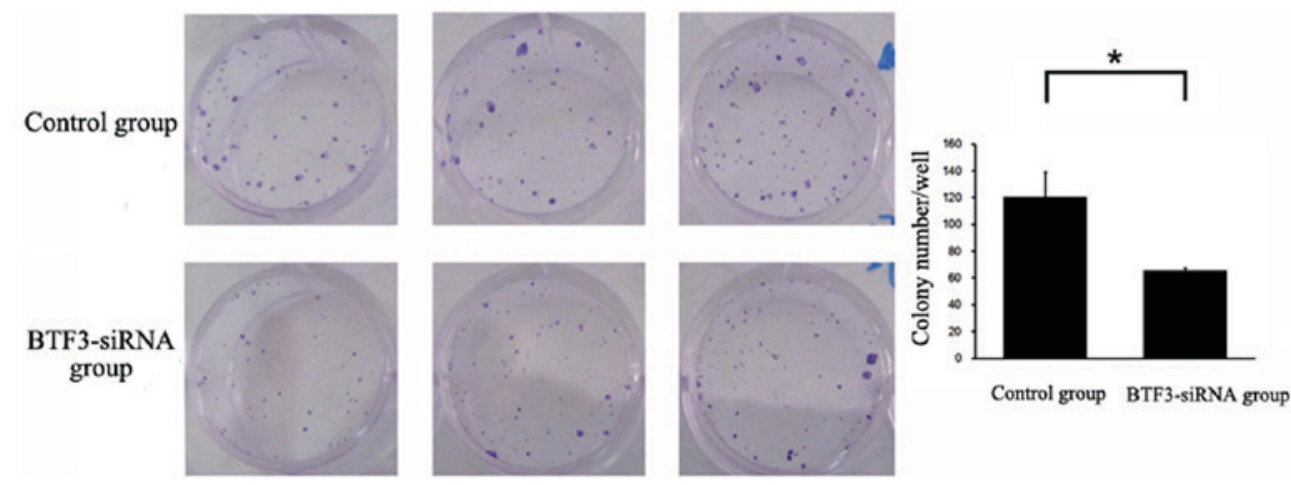

Figure 7. Mean number of colonies in control and siRNA BTF3 groups in TCA- 8113 cells. " $\mathrm{P}<0.05$ compared with control. siRNA, small interfering RNA; BTF3, basic transcription factor 3 .

65 colonies was detected in the siRNA BTF3 group, whereas a significantly higher mean of 121 colonies was detected in the control group $(\mathrm{P}<0.05$; Fig. 7). Compared with the control group, the examined cell lines exhibited a significantly lower colony formation ability following BTF3-silencing.

Follow-up. In the 46 cases of nasopharyngeal tissue, the BTF3 gene was associated with tumor stage, lymph node metastasis and distant metastasis (Table II). The patients with later tumor stage, lymph node metastasis or distant metastasis exhibited a stronger
BTF3 expression compared with those with early tumor stage, negative lymph node metastasis or distant metastasis $(\mathrm{P}<0.05)$.

Survival analysis for BTF3 expression. The Kaplan-Meier analysis of survival with respect to mortality from all causes is illustrated in Fig. 8. A total of 10 mortalities occurred from any cause. Compared with patients with low expression of the BTF3 gene, the patients with high expression had a significantly increased risk of mortality (Log-rank, 7.55; $\mathrm{P}=0.01$ ). Next, survival status was determined using the multivariate Cox proportional hazard 
Table III. Survival status and multivariate analyses in 46 nasopharyngeal carcinoma tissues.

\begin{tabular}{|c|c|c|c|c|c|c|}
\hline \multirow[b]{2}{*}{ Factor } & \multirow[b]{2}{*}{ Total cases } & \multicolumn{3}{|c|}{ Survival status } & \multicolumn{2}{|c|}{ Multivariate analysis } \\
\hline & & Alive & Dead & $\chi^{2}$ test $\mathrm{P}$-value & $\mathrm{P}$-value & Hazard risk $(95 \% \mathrm{CI})$ \\
\hline BTF3 & & & & & & $47.48(1.35-1809.34)$ \\
\hline Low expression & 16 & 14 & 1 & $<0.01$ & 0.03 & \\
\hline High expression & 30 & 21 & 9 & & & \\
\hline Tumor stage $^{a}$ & & & & & & $1.98(0.21-18.46)$ \\
\hline I-II & 14 & 12 & 2 & 0.05 & 0.55 & \\
\hline III-IV & 32 & 24 & 8 & & & \\
\hline LNM & & & & & & $4.95(0.67-36.63)$ \\
\hline None & 18 & 15 & 2 & $<0.01$ & 0.12 & \\
\hline Yes & 28 & 21 & 8 & & & \\
\hline Distant metastasis & & & & & & $0.09(0.16-0.47)$ \\
\hline None & 37 & 33 & 4 & $<0.01$ & 0.01 & \\
\hline Yes & 9 & 3 & 6 & & & \\
\hline \multicolumn{7}{|l|}{ Age, years } \\
\hline$\geq 60$ & 20 & 15 & 5 & 0.31 & & \\
\hline$<60$ & 26 & 21 & 5 & & & \\
\hline \multicolumn{7}{|l|}{ Sex } \\
\hline Male & 41 & 33 & 9 & 0.73 & & \\
\hline Female & 5 & 3 & 1 & & & \\
\hline \multicolumn{7}{|l|}{ Smoking } \\
\hline Frequently & 30 & 25 & 6 & 0.40 & & \\
\hline None & 16 & 11 & 4 & & & \\
\hline
\end{tabular}

${ }^{a}$ American Joint Committee on Cancer Cancer Staging Manual 8th edition (37). $\mathrm{P}<0.05$ was considered to indicate a statistically significant difference. LNM, lymph node metastasis; BTF3, basic transcription factor 3; CI, confidence interval.

model. Metastasis was a significant risk factor in patients with NPC (HR, 0.09; 95\% CI, 0.16-0.47; P=0.01). Furthermore, the positivity for BTF3 (HR, 47.48; 95\% CI, 1.35-1809.34; $\mathrm{P}=0.03$ ) was a significant risk factor for the shorter OS periods observed in patients with NPC (Table III).

\section{Discussion}

Nasopharyngeal carcinoma (NPC) is highly prevalent in Southeast Asia, Southern China, Hong Kong and Taiwan (15). In 2010, data demonstrated that the incidence rate of NPC was $19.5 / 100,000$, while mortality rates was $7.7 / 100,000$ in Southern China (16). The biological behavior and prognosis may be significantly different in patients with NPC with the same stage, histological type or differentiation grade (17). Recently, BTF3 has been revealed to be overexpressed in numerous types of malignant tumor, and has a great influence on gene expression, which is associated with tumor formation and development $(9,10)$.

BTF3 was initially purified from HeLa whole cell extracts $(3,4)$, and is present in two isoforms, BTF3 $\alpha$ and BTF3 $\beta$, which are spliced by the same mRNA (18-20). BTF3 $\alpha$ has all the characteristics of purified BTF3, whereas BTF3 $\beta$ is transcriptionally inactive and lacks the first 44 amino acids of the BTF3 $\alpha$ N-terminus, despite its ability to bind RNA

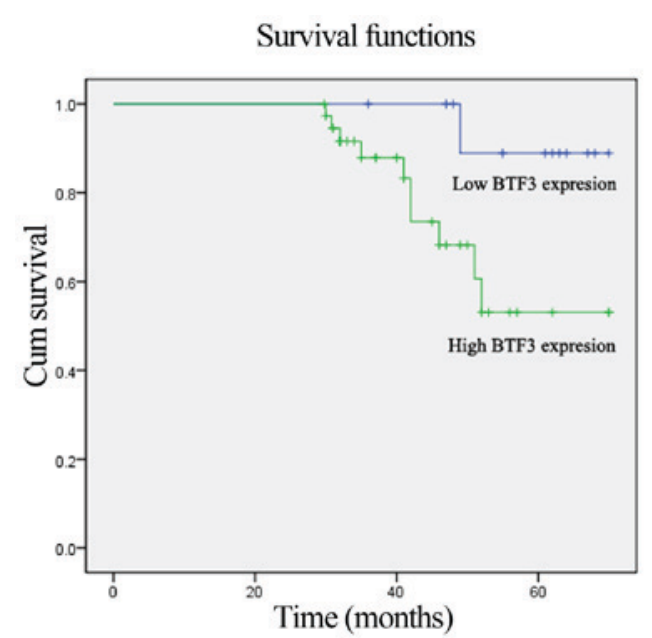

Figure 8. Kaplan-Meier survival curves of patients with NPC based on BTF3 expression status. $\mathrm{P}<0.01$, compared with patients with low expression of the BTF3 gene. Cum, cumulative survival; BTF3, basic transcription factor 3 .

pol II $(1,5,21,22)$. At an early stage of transcription initiation with RNA polymerase II, transcription factor class II D (TFIID) is required to be stably bound to the proximal promoter region, such as the TATA box (2). The BTF3 protein, an additional TF II-related protein, is not directly associated 
with the proximal promoter, but forms a stable complex with RNA polymerase II and is part of the gene transcription initiation complex (23-26).

In addition, BTF3 was demonstrated to be involved in cell cycle regulation and apoptosis (27-29). Using a subclone of the human Burkitt lymphoma BL60 cell line, Brockstedt et al (5) initially discovered that the BTF3 gene was associated with anti-IgM antibody-mediated apoptosis. Downregulation of BTF3 is involved in the inhibition of transcription and protein synthesis in the apoptotic K562 cells induced by harringtonine (7). Later, BTF3 was identified as ICD-1 (Inhibitor of Cell Death-1) in Caenorhabditis elegans, a previously uncharacterized suppressor of apoptosis (6). Bloss et al (6) reported that that loss of ICD-1 leads to inappropriate apoptosis in developing and differentiated cells in various tissues, while overexpression of ICD-1 with CED-4 (caspase-4) participation inhibits the apoptosis of cells that are normally programmed to die (6).

In addition, BTF3 is important in growth development and morphogenesis (30). Deng and Behringer (8) transmitted a BTF3 mutation through the germline of chimeric mice, and identified that mice homozygous for the mutant allele died soon after implantation (8).

In the present study, the BTF3 gene was demonstrated to be overexpressed in NPC tissues compared with adjacent normal tissues, which is consistent with results in glioblastoma multiform (31-33), hepatic and gastric (34-36), pancreatic (9) and prostatic cancer (10). In addition, immunohistochemical staining is also increased with an increasing degree of tumor differentiation, which is consistent with pancreatic (36), prostatic (10) and colorectal cancer (27-29). The expression of BTF3 is much higher in advanced tumor stages and lymph node metastasis. In addition, at follow-up, BTF3 was identified to have a significant association with tumor stage, lymph node metastasis and distant metastasis. Furthermore, the data demonstrated that patients with high BTF3 expression had a significantly lower survival rate than those with low levels of BTF3. This may be due to the BTF3 gene participating in cell apoptosis, decreasing programmed cell death and promoting the growth of tumor cells $(6,30)$.

In the present study, siRNA-BTF3 was used to downregulate BTF3 expression in 5-8F and TCA-8113 cells. BTF3-silencing was demonstrated to decrease cell proliferation, particularly in TCA-8113 cells. Furthermore, compared with the control group, following BTF3-silencing, cells exhibited a significantly lower colony formation ability. This may be associated with cell cycle arrest following BTF3-silencing. BTF3-silencing may induce $\mathrm{G} 1$ to $\mathrm{G} 2 / \mathrm{M}$ or $\mathrm{S}$ phase failure, which leads to the inhibition of cell cycle completion and postponement of cell multiplication. By contrast, the BTF3 gene participates in the process of apoptosis (9), including anti-IgM antibody-mediated apoptosis (30) or apoptosis with caspase-4 (CED-4) participation (6). In addition, BTF3 may inhibit the apoptosis path by affecting several tumor correlation factors.

A number of limitations are indicated in the present study. The possibility of selection biases exists, which may have affected either the patients referred to the institution or the patients recruited in the present study. In addition, the performance of apoptosis experiments and cell cycle experiments are required in future examination of BTF3 gene function.

In summary, the results of the present study demonstrated that BTF3 mRNA and protein were overexpressed in patients with NPC, which was associated with tumor stage, lymph node metastasis and distant metastasis. In addition, patients with a high expression of BTF3 had a significantly increased risk of overall death, which indicated that the BTF3 gene was associated with the progression and prognosis of NPC. Furthermore, silencing of BTF3 may inhibit tumor growth and cloning ability, due of its association with cell proliferation and the process of apoptosis. Therefore, the results of the present study indicated that BTF3 may contribute toward the development, progression and prognosis of NPC, and may provide evidence at the molecular level for the targeted therapy of NPC.

\section{Acknowledgements}

Not applicable.

\section{Funding}

The present study was supported by the Beijing Health System High-level Health Technology Talents Training Project Funding (grant no. 2015-3-022); the National Natural Science Foundation of China, (grant no. 81670946); the Beijing Municipal Administration of Hospitals Clinical Medicine Development of Special Funding Support (grant no. XMLX201507); Capital's Funds for Health Improvement and Research (grant no. CFH2018-1-2052) and the Beijing Municipal Administration of Hospitals Incubating Program (grant no. PX2017032).

\section{Availability of data and materials}

The datasets used and/or analyzed during the current study are available from the corresponding author on reasonable request.

\section{Authors' contributions}

PC performed the histological examination and was a major contributor in writing the manuscript. QZ made contributions on conception and design and analyzed the patient data. ZL interpreted the patient data and cell experiment data. YZ and $\mathrm{ZH}$ made substantial contributions to conception and interpreted the data. All authors read and approved the final manuscript.

\section{Ethics approval and consent to participate}

The present study was approved by the Ethics Committee of Beijing Tongren Hospital Capital Medical University (approval no. TRECKY2014-027; Beijing China) and informed consent in written form was obtained from all participants.

\section{Patient consent for publication}

The patients provided written informed consent for publication. 


\section{Competing interests}

The authors declare that they have no competing interests.

\section{References}

1. Kanno M, Chalut C and Egly JM: Genome structure of the putative BTF3 transcription factor. Gene 117: 219-228, 1992

2. Zheng XM, Black D, Chambon P and Egly JM: Sequencing and expression of complementary DNA for the general transcription factor BTF3. Nature 344: 556-559, 1990.

3. Cavallini B, Huet J, Plassat JL, Sentenac A, Egly JM and Chambon P: A yeast activity can substitute for the HeLa cell TATA box factor. Nature 334: 77-80, 1988

4. Zheng XM, Moncollin V, Egly JM and Chambon P: A general transcription factor forms a stable complex with RNA polymerase B (II). Cell 50: 361-368, 1987.

5. Brockstedt E, Otto A, Rickers A, Bommert K and Wittmann-Liebold B: Preparative high-resolution two-dimensional electrophoresis enables the identification of RNA polymerase $\mathrm{B}$ transcription factor 3 as an apoptosis-associated protein in the human BL60-2 Burkitt lymphoma cell line. J Protein Chem 18: 225-231, 1999.

6. Bloss TA, Witze ES and Rothman JH: Suppression of CED-3-independent apoptosis by mitochondrial betaNAC in Caenorhabditis elegans. Nature 424: 1066-1071, 2003.

7. Li R, Liu XL, Du QF, Zhang S, Luo RC and Zhou SY: Proteome analysis of apoptotic K562 cells induced by harringtonine. Zhonghua Xue Ye Xue Za Zhi 25: 323-327, 2004 (In Chinese).

8. Deng JM and Behringer RR: An insertional mutation in the BTF3 transcription factor gene leads to an early postimplantation lethality in mice. Transgenic Res 4: 264-269, 1995.

9. Kusumawidjaja G, Kayed H, Giese N, Bauer A, Erkan M, Giese T, Hoheise JD, Friess $\mathrm{H}$ and Kleeff J: Basic transcription factor 3 (BTF3) regulates transcription of tumor-associated genes in pancreatic cancer cells. Cancer Biol Ther 6: 367-376, 2007.

10. Symes AJ, Eilertsen M, Millar M, Nariculam J, Freeman A, Notara M, Feneley MR, Patel HR, Masters JR and Ahmed A: Quantitative analysis of BTF3, HINT1, NDRG1 and ODC1 protein over-expression in human prostate cancer tissue. PLoS One 8: e84295, 2013.

11. Pasquale EB: Eph receptors and ephrins in cancer: Bidirectional signalling and beyond. Nat Rev Cancer 10: 165-180, 2010 Surawska H, Ma PC and Salgia R: The role of ephrins and Eph receptors in cancer. Cytokine Growth Factor Rev 15: 419-433, 2004.

12. Chiang AK Mak NK and Ng WT: Translational research in nasopharyngeal carcinoma. Oral Oncol 50: 345-352, 2014.

13. Yang S, Wu S, Zhou J and Chen XY: Screening for nasopharyngeal cancer. Cochrane Database Syst Rev 11: CD008423, 2015.

14. Livak KJ and Schmittgen TD: Analysis of relative gene expression data using real-time quantitative PCR and the 2(-Delta Delta C(T)) method. Methods 25: 402-408, 2001

15. Chia WK, Teo M, Wang WW, Lee B, Ang SF, Tai WM, Chee CL, $\mathrm{Ng} \mathrm{J}$, Kan R, Lim WT, et al: Adoptive T-cell transfer and chemotherapy in the first-line treatment of metastatic and/or locally recurrent nasopharyngeal carcinoma. Mol Ther 22: 132-139, 2014

16. Hong Kong Cancer Registry. Available online: http://www3. ha.org.hk/cancereg/Statistics.html (accessed on 20 August 2013)

17. Chen ZT, Liang ZG and Zhu XD: A review: Proteomics in nasopharyngeal carcinoma. Int J Mol Sci 16: 15497-15530, 2015.

18. Hayashi S, Andoh T and Tani T: EGD1 ( $\beta$-NAC) mRNA is localized in a novel cytoplasmic structure in Saccharomyces cerevisiae. Genes Cells 16: 316-329, 2011.

19. Kirstein-Miles J, Scior A, Deuerling E and Morimoto RI: The nascent polypeptide-associated complex is a key regulator of proteostasis. EMBO J 32: 1451-1468, 2013.
20. Zhang Y, Berndt U, Gölz H, Tais A, Oellerer S, Wölfle T, Fitzke E and Rospert S: NAC functions as a modulator of SRP during the early steps of protein targeting to the endoplasmic reticulum. Mol Biol Cell 23: 3027-3040, 2012.

21. Beatrix B, Sakai H and Wiedmann M: The alpha and beta subunit of the nascent polypeptide-associated complex have distinct functions. J Biol Chem 275: 37838-37845, 2000.

22. Franke J, Reimann B, Hartmann E, Köhlerl M and Wiedmann B: Evidence for a nuclear passage of nascent polypeptide-associated complex subunits in yeast. J Cell Sci 114: 2641-2648, 2001.

23. Bukau B, Deuerling E, Pfund C and Craig EA: Getting newly synthesized proteins into shape. Cell 101: 119-122, 2000.

24. Hartl FU and Hayer-Hartl M: Molecular chaperones in the cytosol: From nascent chain to folded protein. Science 295: $1852-1858,2002$.

25. Wegrzyn RD and Deuerling E: Molecular guardians for newborn proteins: ribosome-associated chaperones and their role in protein folding. Cell Mol Life Sci 62: 2727-2738, 2005.

26. Powers $T$ and Walter P: The nascent polypeptide-associated complex modulates interactions between the signal recognition particle and the ribosome. Curr Biol 6: 331-338, 1996.

27. Thiede B, Dimmler C, Siejak F and Rudel T: Predominant identification of RNA-binding proteins in Fas-induced apoptosis by proteome analysis. J Biol Chem 276: 26044-26050, 2001.

28. Thakur D, Saxena R, Singh V, Haq W, Katti SB, Singh BN and Tripathi RK: Human beta casein fragment (54-59) modulates $M$. bovis BCG survival and basic transcription factor 3 (BTF3) expression in THP-1 cell line. PLoS One 7: e45905, 2012.

29. Pham VC, Pitti R, Anania VG, Bakalarski CE, Bustos D, Jhunjhunwala S, Phung QT, Yu K, Forrest WF, Kirkpatrick DS, et al: Complementary proteomic tools for the dissection of apoptotic proteolysis events. J Proteome Res 11: 2947-2954, 2012.

30. Yang KS, Kim HS, Jin UH, Lee SS, Park JA, Lim YP and Pai HS: Silencing of NbBTF3 results in developmental defects and disturbed gene expression in chloroplasts and mitochondria of higher plants. Planta 225: 1459-1469, 2007.

31. Odreman F, Vindigni M, Gonzales ML, Niccolini B, Candiano G, Zanotti B, Skrap M, Pizzolitto S, Stanta G and Vindigni A: Proteomic studies on low- and high-grade human brain astrocytomas. J Proteome Res 4: 698-708, 2005.

32. Kunkle BW, Yoo C and Roy D: Reverse engineering of modified genes by Bayesian network analysis defines molecular determinants critical to the development of glioblastoma. PLoS One 8: e64140, 2013.

33. Jain R, Kulkarni P, Dhali S, Rapole S and Srivastava S: Quantitative proteomic analysis of global effect of LLL12 on U87 cell's proteome: An insight into the molecular mechanism of LLL12. J Proteomics 113: 127-142, 2015.

34. Uhlen M, Oksvold P, Fagerberg L, Lundberg E, Jonasson K, Forsberg M, Zwahlen M, Kampf C, Wester K, Hober S, et al: Towards a knowledge-based human protein atlas. Nat Biotechnol 28: 1248-1250, 2010.

35. Liu Q, Zhou JP, Li B, Huang ZC, Dong HY, Li GY, Zhou K and Nie SL: Basic transcription factor 3 is involved in gastric cancer development and progression. World J Gastroenterol 19: 4495-4503, 2013

36. Roy L, Laboissière S, Abdou E, Thibault G, Hamel N, Taheri M, Boismenu D, Lanoix J, Kearney RE and Paiement J: Proteomic analysis of the transitional endoplasmic reticulum in hepatocellular carcinoma: An organelle perspective on cancer. Biochim Biophys Acta 1804: 1869-1881, 2010.

37. Amin MB, Edge SB, Greene FL, et al: AJCC cancer staging manual. 8th edition. New York, Springer, 2017.

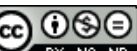

This work is licensed under a Creative Common Attribution-NonCommercial-NoDerivatives 4.0 International (CC BY-NC-ND 4.0) License. 